\title{
Regulated Deficit Irrigation and Onion (Allium cepa L.) Yield Response on Water Productivity
}

\author{
Gebeyehu Tegenu \\ Ethiopian Agricultural Research Institute Debre Zeit Agricultural Research Center P.O.Box 32, Debre Zeit, \\ Ethiopia
}

\begin{abstract}
Irrigation is the only solution to improve crop production and productivity thereby contributing towards food security, self-sufficiency and export market. The efficient use of water by irrigation system is becoming increasingly important in arid and semi-arid regions with limited water resources. The Experiment was conducted in Debre Zeit Agricultural Research Center with the Regulated Deficit Irrigation and Onion (Allium cepa L.) Yield Response on Water Productivity in Ethiopia during 2017/2018 cropping season. The objective of the experiment was identify the pin point of water stress threshold value of onion under deficit irrigation and investigate the effect of alternate, fixed and conventional furrow irrigation methods on crop yield and water productivity under deficit irrigation. The experimental treatments had three furrow irrigation methods, (alternate furrow irrigation (AFI), fixed furrow irrigation (FFI) and conventional furrow irrigation (CFI)) and two deficit irrigation levels of application, viz., $85 \%$ ETc, and $70 \%$ ETc and a control irrigation of $100 \% \mathrm{ETc}$. The design of the experimental plot was split plot in RCBD arrangement and replicated three times. The three furrow irrigation methods were arranged as main plots and the deficit levels as sub plots a total of nine (9) treatment combinations. All collected data, were statistically analyzed using SAS 9.1 statistical software. The experimental study result showed that bulb diameter, unmarketable bulb yield and total bulb yield of onion were highly significance difference $(p<0.001)$ both in furrow irrigation methods and irrigation levels. Likewise diameter of onion also gave highest on CFI and $100 \%$ ETc irrigation water application level which is $6.69 \mathrm{~cm}$ and $6.94 \mathrm{~cm}$ respectively. According to the results obtained, the highest total yield was recorded for the treatment of $100 \% \mathrm{ETc}$ irrigation water application and AFI of the furrow irrigation method $38947 \mathrm{kgha}^{-1}$ and $35920 \mathrm{kgha}^{-1}$ respectively however, the lowest total bulb yield of $30253 \mathrm{~kg} \mathrm{ha}^{-1}$ and $29135 \mathrm{~kg} \mathrm{ha}^{-1}$ were recorded when FFI system was applied and in $70 \%$ ETc of water applied. Bulb height of onion was highly significance difference $(p<0.001)$ only on deficit irrigation levels. On the other hand, marketable bulb yield, irrigation water use efficiency and crop water use efficiency were significance difference $(\mathrm{P} \leq 0.05)$ by the interaction of furrow irrigation methods and deficit irrigation levels. The highest average marketable bulb yield of onion was obtained $42219 \mathrm{kgha}^{-1}$ on CFI with the combination of $100 \% \mathrm{ETc}$ irrigation level in addition to this IWUE and CWUE both are recorded highest result on $70 \% \mathrm{ETc}$ and AFI furrow irrigation method. Generally, among all irrigation treatments $70 \%$ ETc deficit irrigation level applied under AFI method was efficient in conserving significant irrigation water. Therefore, it could be concluded that, AFI can save a substantial amount of water and labor without highly reduction of onion yield and the lowest CWUE and IWUE was gave FFI followed by CFI.
\end{abstract}

Keywords: Alternate furrow irrigation, Conventional furrow irrigation, Deficit irrigation, fixed furrow irrigation, Onion

DOI: $10.7176 / J R D M / 71-02$

Publication date: November $30^{\text {th }} 2020$

\section{INTRODUCTION}

Food insecurity has been the problem of Ethiopia for many years and recurrent droughts have been one of the major problems during the past three decades. The occurrence of drought in most parts of the country is usually caused by insufficient rainfall to support the seasonal water requirements of the rain-fed crop production. About $80 \%$ of the country's population is dependent on rain-fed agriculture and inadequate seasonal rainfall has caused serious food shortages that can adversely destabilize the social and economic life of the people (World Bank, 2006).Irrigated agriculture makes a major contribution to food security, producing nearly $40 \%$ of food and agricultural commodities on $17 \%$ of agricultural land in the World. Irrigated areas have almost doubled in recent decades and contributed much to the growth in agricultural productivity over the last 50 years. Agriculture accounts for about $70 \%$ of the freshwater withdrawals in the world (FAO, 2013), while consumptive use of water in agriculture (water that is evaporated from irrigated fields) accounts for about $90 \%$ of all of the water that is evaporated as a result of human intervention. Irrigated agriculture is therefore the main reason for water demand and a driver of scarcity of fresh water in a number of regions.

In the $20^{\text {th }}$ century, worldwide irrigated area experienced a huge expansion of more than $500 \%$ increase from 40 million to 270 million ha of irrigated land. Such numbers are part of the ability of humankind to produce food fast enough to meet population growth. But that remarkable ability, on the other hand, has its cost - a water crisis, characterized by water scarcity and competition, pollution and malnutrition (Molden, 2003). 
Agriculture is the dominant sector in Ethiopian economy contributing about $45 \%$ to the gross domestic product (GDP) and $85 \%$ to export earnings. The cultivated land in the country is mostly rain-fed and subsequently variability of rainfall during the cropping season affects crop production and productivity. To solve such problems irrigation is an important. Irrigation not only improves crop production and productivity, but also reduces reliance on rainfall, contribute towards food security, self-sufficiency and export market.

Water availability is considered the climatic factor with greatest effect on agricultural productivity (Falkenmark and Rockstrom, 2000). Aranus et al. (2003) reported that, among the environmental factors affecting crops, the water input, expressed as the sum of rainfall and irrigation during the growing period, explained the large part of the yield variability.

Irrigation development is increasingly implemented in Ethiopia more than ever to supplement the rain-fed agriculture. It aims to increase agricultural productivity and diversify the production of food and raw materials for agro-industry as well as to ensure that the agriculture to play a pivotal for driving the economic development of the country (Mekonen, 2011). But, the overall performance of the crop production is still hindered due to unsustainable water supply. The scope for further irrigation development to meet food requirements in future is, however, severely constrained by decreasing water resources and growing competition for clean water. While on a global scale, water resources are still ample. Serious water shortages are developing in the arid and semi-arid regions as existing water resources reach full exploitation. The situation is exacerbated by the declining quality of water and soil resources. The dependency on water has become a critical constraint on further progress and threatens to slow down development, endangering food supplies and aggravating rural poverty. The great challenge for the coming decades will therefore be the task of increasing food production with less water, particularly in countries with limited water and land resources.

Water stress affects yield productivity in many ways. Most of the responses have a negative effect on production. But crops have different and often complex mechanisms to react to shortages of water. Several crops and genotypes have developed different degrees of drought tolerance, drought resistance or compensatory growth to deal with periods of stress. The highest crop productivity is achieved for high-yielding varieties with optimal water supply and high soil fertility levels, but under conditions of limited water supply crops will adapt to water stress and can produce well with less water (FAO, 2002).

The use of fixed and alternate furrow irrigation methods allows for a reduction in volume irrigation water and completion of irrigation application in shorter time, thus reducing labor use when compared to conventional furrow irrigation method. Scientist observed a highly significant crop yield differences from alternate furrow relative to conventional furrow method Kang et al. (1999).

Onion is one of the most cultivated vegetable crops in the world. It is produced in many countries both under rain fed and irrigation conditions. According to World Bank (2004) report in 2001 the crop shared one fourth of the vegetable export quantities and stood third following green beans and peas contributing about $20 \%$ of the total vegetable export value which is about 244,000 US dollar of export earnings.

Global production of onions in 2008 was second only to tomatoes among horticultural crops: more than 73 million metric tons harvested from 3.6 million hectares. China alone produced more than 20 million metric tons; other leading producers were India, Australia, the United States, Pakistan, and Turkey (FAOSTAT, 2011). In Africa Egypt, Algeria, Morocco, Nigeria, South Africa and Niger are the leading producers of the crop in Africa (FAOSTAT, 2008). In Ethiopia, the crop is one of the most important vegetables produced by smallholder farmers mainly as a source of cash income and for flavoring the local stew 'wot' (Lemma and Shemelis, 2003; Fekadu et al., 2006). In 2016/17, the total area under onion production in Ethiopia is estimated to be 33603.39 ha with an average yield of about 97.45 Qt per ha (CSA, 2015/16).

The country has high potential to benefit from onion production. To attain the genetic potential yield and achieve high economic growth from onion production and productivity, it is necessary to study the response onion to different deficit irrigation levels and different furrow irrigation application methods. The experimental treatments had three furrow irrigation methods, viz., alternate furrow irrigation (AFI), fixed furrow irrigation (FFI) and conventional furrow irrigation (CFI) and three deficit irrigation levels of application, viz., $85 \%$ ETc, $70 \%$ ETc and $55 \% \mathrm{ETc}$, and a control irrigation of $100 \% \mathrm{ETc}$.Crop water requirement or crop evapotranspiration (ETc).

The objective of the study was to investigate the effect of furrow irrigation methods and identify optimal deficit irrigation level on crop yield and water productivity of onion under central highland environment condition.

\section{MATERIALS AND METHODS}

\subsection{Description of the Study Area}

The Experiment was conducted in 2017/18 cropping season at Debre Zeit Agricultural Research Center, main station which about $47 \mathrm{~km}$ Southeastern of Addis Ababa. The geographical location extent ranges to $08^{\circ} 44^{\prime} 15^{\prime \prime}$ to $08^{\circ} 46^{\prime} 45^{\prime \prime} \mathrm{N}$ Northern latitude and from $38^{\circ} 59^{\prime} 45^{\prime}$ to $39^{\circ} 01^{\prime} 00^{\prime \prime}$ E Eastern longitude. The research center is located on a nearly level of a very gently sloping topography with a gradient of zero to $2 \%$ slope. It has low relief difference with altitude ranging from 1610 to 1908 meters above the sea level. The site is situated in the Central 
high land area of the country having Tepid to cool sub-moist highlands type climate. The area receives an annual mean rainfall of $851 \mathrm{~mm}$. The mean maximum and minimum temperature are $28.3^{\circ} \mathrm{C}$ and $8.9^{\circ} \mathrm{C}$, respectively with the average value of $19^{\circ} \mathrm{C}$. The experimental fields are dominated by heavy soils (Vertisol) (WRB, 2014).

Soil samples were collected from experimental plots after irrigation for gravimetric soil moisture determination from different depths Physical and Chemical properties of soil data Soil texture, Bulk density, Field capacity(FC), permanent wilting point(PWP), electrical conductivity of soil (ECe), cat ion exchange capacity of soil (CEC ),organic matter and soil $\mathrm{pH}$. Chemical properties of irrigation water Electrical conductivity of irrigation water $(\mathrm{ECw})$ and irrigation water $\mathrm{PH}$.

The soil samples were analyzed at Debre Zeit Agricultural research center's soil laboratory for physical (texture, Field Capacity (FC), Permanent wilting Point (PWP)) and chemical quality (pH, Organic Matter (OM), Electrical Conductivity (EC) and Cat ion Exchange Capacity (CEC) parameters at laboratory following standard test procedures. The FC and PWP were determined using pressure plate and membrane apparatus by applying a pressure of 0.33 bars and 15 bars, respectively, on saturate soil paste until no change in moisture is detected. The soil texture was analyzed using hydrometer method. The soil $\mathrm{pH}$ was determined by measuring soil solution of 1:2.5 ratios (soil to water) using a $\mathrm{pH}$ meter. The Organic carbon (\%) was determined following the wet digestion method as described by Walkley and Black (1934). OM content was then determined by multiplying OC by 1.724 (Nelson and Sommers, 1996). The ECe was determined by measuring the conductivity of saturated soil extract using electrical conductivity meter.

Onion seeds variety Nafis was used as seed material. The selected seed variety was sown in Oct 2017 on nursery bed. The seedlings were then transplanted in Dec 2017 on well prepared experimental plots and the seedlings were established in both sides of a ridge with row and plant spacing of $20 \mathrm{~cm}$ and $10 \mathrm{~cm}$, respectively.

Cultural practices are dates of site selection, Land preparation, soil sampling, amount and frequency of pre irrigation, seedling preparation, transplanting, treatment application, crop management practice like wedding, cultivating and pesticide application, maturity and harvest recording of, Fertilizer Application time, crop growth length period and harvesting date.

When the crop approaches to maturity simply by observing leaves of onion when $50 \%$ of its leaves dawn off harvested on the field.

Marketable bulb yield $\left(\mathrm{kg} \mathrm{ha}^{-1}\right)$ refers to yield of onions, which are not under sized ( $>5 \mathrm{~cm}$ in diameter), free from physiological disordered and pest damaged bulbs. It was determined from weight of bulbs harvested from the net plot using digital balance.

Unmarketable bulb yield $\left(\mathrm{kg} \mathrm{ha}^{-1}\right)$ refers to sized, color, physiological disordered and pest damaged bulbs which was determined from weight of bulbs harvested from the net plot using digital balance.(Moray et al., 2012). Onion bulbs with less than $5 \mathrm{~cm}$ diameter were categorized under unmarketable (Moray et al., 2012). The source of irrigation water in the study area is ground water with the depth of $60 \mathrm{~m}$ to irrigate the crop with the help of electric water pump.

\subsection{Treatments and Experimental Design}

The Experiment was conducted in 2017/18 cropping season at Debre Zeit Agricultural Research Center. The experimental treatments had three furrow irrigation methods, viz., alternate furrow irrigation (AFI), fixed furrow irrigation (FFI) and conventional furrow irrigation (CFI) and two deficit irrigation levels of application, viz., $85 \%$ ETc and $70 \%$ ETc and a control irrigation of $100 \% \mathrm{ETc}$. Crop water requirement or crop evapotranspiration (ETc). The design of the experimental plot was split plot in RCBD arrangement and replicated three times. The three furrow irrigation methods were arranged as main plots and the deficit levels as sub plots. The experiment had a total of nine (9) treatment combinations. The experimental field was divided into 27 plots with $3.6 \mathrm{~m}$ by $4 \mathrm{~m}$ plot size to accommodate six furrows with spacing of $60 \mathrm{~cm}$ having row and plant spacing of $20 \mathrm{~cm}$ and $10 \mathrm{~cm}$, respectively. The plots and replications had a buffer zone of $2 \mathrm{~m}$ for canals carrying no irrigation water and $2.5 \mathrm{~m}$ for canals carrying irrigation water supply canals between plots to eliminate influence of lateral water movement and also $1 \mathrm{~m}$ between plots. The experimental treatment combination is given in Table 1

Table 1. Treatment combination

\begin{tabular}{|l|l|l|l|}
\hline \multirow{2}{*}{$\begin{array}{l}\text { Sub-plot } \\
\text { Irrigation Level }\end{array}$} & Main-plot - Furrow Irrigation Method & \multicolumn{2}{|l|}{} \\
\cline { 2 - 4 } & AFI & FFI & CFI \\
\hline $100 \%$ ETc & T1 & T4 & T7 \\
\hline $85 \%$ ETc & T2 & T5 & T8 \\
\hline $70 \%$ ETc & T3 & T6 & T9 \\
\hline
\end{tabular}

\subsection{Statistical Analysis}

The collected data were statistically analyzed appropriate to Split-plot design using statistical software which is Statistical Analysis System (SAS). Whenever the treatment effects were found significant, least significant difference (LSD) test was performed to assess any significant difference among treatments means. 


\section{Results and discussion}

The different deficit irrigation levels under alternate, fixed and conventional furrow irrigation methods had shown a significant effect on onion bulb length and diameter, yield and yield components. The results are shown in subsection below together with analysis of the experimental soil and climate characteristics.

\subsection{Soil Sampling and Analysis}

The results of soil analyses and field tests on physical and chemical characteristic are given in Table 2 and 3.

\subsubsection{Soil Physical Characteristics}

The laboratory analysis indicates that the basis particle size distribution in the soil was average value of $53.60 \%$ clay, $22.53 \%$ sand and $23.87 \%$ silt at experimental site. Therefore based on soil textural class determination triangle of international soil society (ISSS) system (Rowell, 1994) the soil of the experimental site was clay in texture. The bulk density of the experimental site showed slight variation with depth and varied from 1.04 to $1.15 \mathrm{~g} / \mathrm{cm}^{3}$. This could be because of slight decrease of organic matter with depth and compaction due to the weight of the overlying soil layer (Brady and Weil, 2002). The weighted bulk density (BD) and Total Available Water (TAW) of the experimental site are given in Table 2.

\section{Table 2. Soil physical properties}

\begin{tabular}{lllllllll}
\hline $\begin{array}{l}\text { Depth } \\
(\mathbf{c m})\end{array}$ & BD $(\mathbf{g} / \mathbf{c m 3})$ & $\mathbf{F C}(\%)$ & PWP $(\%)$ & TAW $(\mathbf{m m})$ & Clay & $\mathbf{( \% )} \begin{array}{l}\text { Sand } \\
(\%)\end{array}$ & Silt (\%) & $\begin{array}{l}\text { Textural } \\
\text { class }\end{array}$ \\
\hline $\mathbf{0 - 2 0}$ & 1.04 & 39.35 & 23.76 & 32.43 & 53.6 & 23.2 & 23.2 & Clay \\
$\mathbf{2 0 - 4 0}$ & 1.1 & 41.94 & 24.58 & 38.19 & 55.6 & 25.2 & 19.2 & Clay \\
$\mathbf{4 0 - 6 0}$ & 1.15 & 39.9 & 24.94 & 34.41 & 51.6 & 19.2 & 29.2 & Clay \\
Average & 1.01 & 40.40 & 24.43 & 35.01 & 52.93 & 22.53 & 23.87 & Clay \\
\hline
\end{tabular}

Note: FC: Field Capacity PWP: Permanent Wilting Point

\subsubsection{Soil Chemical Characteristics and Water Properties}

Soil PH is an important parameter which measures hydrogen ion concentration in the soil to indicate its acidic and alkaline nature of the soil. According to Murphy (1968) rating scale, the $\mathrm{pH}$ value of the current experimental site soils was near to neutral ( $\mathrm{pH} 7.07$ ). Onion can grow well in soil $\mathrm{pH}$ range from 6.0 to 8.0 (Olani and Fikre, 2010). The soil had a Cation exchange capacity $(12.77 \mathrm{meq} / 100 \mathrm{~g})$ through $60 \mathrm{~cm}$ profile and average electrical conductivity of $(0.280 \mathrm{ds} / \mathrm{m})$ which is below the threshold value for onion yield reduction, i.e. $1.2 \mathrm{dS} / \mathrm{m}$ (Smith et al. , 2011). Organic matter content (OM) improves water-holding capacity, nutrient release and soil structure. The OM content and OC content of the soil had average values of $1.80 \%$ and $1.05 \%$, respectively which is rated as low.The findings of Tekalign (1991) who reported that soils having OM value in the range of $0.86-2.59 \%$ are considered low.

The laboratory result of the irrigation water showed the $\mathrm{pH}$ value of 7.47 and $\mathrm{ECw}$ value of $0.67 \mathrm{dS} \mathrm{m} \mathrm{m}^{-1}$ (Table 3). According to Bryan et al. (2007), the irrigation water is classified in terms of $\mathrm{pH}$ as low (below 7), slight to moderate (7-8) and severe (above 8). Based on this classification, the characteristics of the irrigation water in the study area are found slight to moderate (Table 3 ).

Bauder et al. (2014), who reported that, irrigation water quality salinity hazard, has four categories: $(\leq 0.75$ $\mathrm{dS} \mathrm{m}{ }^{-1}$ none), (0.76-1.5 $\mathrm{dS} \mathrm{m}^{-1}$ some), (1.51-3.00 dS m${ }^{-1}$ moderate) and ( $\geq 3.00 \mathrm{dS} \mathrm{m}^{-1}$ severe). Based on the above categories the irrigation water quality of the study area was classified at none.

Table 3: Soil chemical and Water properties

\begin{tabular}{llllll}
\hline Depth $(\mathrm{cm})$ & $\mathrm{pH}$ & $\mathrm{CEC}(\mathrm{meq} / 100)$ & $\mathrm{EC}(\mathrm{ds} / \mathrm{m})$ & OC $(\%)$ & OM $(\%)$ \\
\hline $0-20$ & 7.10 & 14.7 & 0.298 & 1.15 & 1.98 \\
$20-40$ & 7.11 & 13.9 & 0.265 & 1.12 & 1.93 \\
$40-60$ & 7.00 & 9.7 & 0.278 & 0.87 & 1.50 \\
Average & 7.07 & 12.77 & 0.280 & 1.05 & 1.80 \\
Irrigation Water & & & & & \\
$\mathrm{pH}$ & 7.47 & & & & \\
ECw & $0.67 \mathrm{ds} / \mathrm{m}$ & & & & \\
\hline
\end{tabular}

Note: OC: Organic Carbon

\subsection{Crop water requirement and Irrigation water management}

The reference evapotranspiration ETo value of the experimental site ranged between $4.62 \mathrm{~mm} /$ day in December to $5.95 \mathrm{~mm} /$ day in March, with an average of $4.89 \mathrm{~mm} /$ day for the whole growth period. Using the reference evapotranspiration (ETo) and crop coefficient value (KC), calculation of the total seasonal onion crop water requirement or crop evapotranspiration (ETc) was found to be $436.14 \mathrm{~mm}$ (Table 4). This amount was needed for 
full irrigation level treatments $(100 \% \mathrm{ETc})$. Accordingly, the $85 \% \mathrm{ETc}$ and $70 \% \mathrm{ETc}$ of irrigation level with the furrow irrigation methods of CFI were applied $370.72 \mathrm{~mm}$, and $305.30 \mathrm{~mm}$ with AFI and FFI with the same value of $100 \%$ ETc, $85 \%$ ETc and $70 \%$ ETc were $218.07 \mathrm{~mm}$ and $185.36 \mathrm{~mm}$ respectively (table 4 ). The Crop water requirement (ETc) values were low at the beginning of the initial growing season, increased gradually to attain a maximum during development and mid stage and subsequently decreased based on crop growth stages and climate data.

Table 4. Irrigation interval, number and depth of irrigation

\begin{tabular}{|l|l|l|l|l|l|}
\hline Treatments & $\begin{array}{l}\text { Number of } \\
\text { Furrow } \\
\text { Irrigation }\end{array}$ & $\begin{array}{l}\text { Irrigation } \\
\text { level (\%) }\end{array}$ & $\begin{array}{l}\text { Days between } \\
\text { irrigation } \\
\text { (interval) }\end{array}$ & $\begin{array}{l}\text { Net Irrigation } \\
(\mathrm{In}) \\
(\mathrm{mm})\end{array}$ & $\begin{array}{l}\text { Gross Irrigation (Ig) } \\
(\mathrm{mm})\end{array}$ \\
\hline \multirow{4}{*}{ CFI } & $100 \%$ & 19 & 7 & 436.14 & 726.9 \\
\cline { 2 - 6 } & $85 \%$ & 19 & 7 & 370.72 & 617.9 \\
\cline { 2 - 6 } & $70 \%$ & 19 & 7 & 305.30 & 508.8 \\
\hline \multirow{3}{*}{ AFI } & $100 \%$ & 19 & 7 & 218.07 & 363.5 \\
\cline { 2 - 6 } & $85 \%$ & 19 & 7 & 185.36 & 308.9 \\
\hline \multirow{3}{*}{ FFI } & $70 \%$ & 19 & 7 & 152.65 & 254.4 \\
\cline { 2 - 6 } & $100 \%$ & 19 & 7 & 218.07 & 363.5 \\
\cline { 2 - 6 } & $85 \%$ & 19 & 7 & 185.36 & 308.9 \\
\cline { 2 - 6 } & $70 \%$ & 19 & 7 & & 254.4 \\
\hline
\end{tabular}

Table 5. Crop water requirement and Irrigation water requirement of onion (100\% ETc)

\begin{tabular}{|l|l|l|l|l|l|l|l|}
\hline Date & $\begin{array}{l}\text { ETo } \\
\text { Mm }\end{array}$ & Kc & $\begin{array}{l}\text { CWR/ ETc } \\
(\mathrm{mm})\end{array}$ & $\begin{array}{l}\text { Rainfall }(\mathrm{P}) \\
(\mathrm{mm})\end{array}$ & $\begin{array}{l}\mathrm{P}_{\text {eff }} \\
(\mathrm{mm})\end{array}$ & $\begin{array}{l}\text { In } \\
(\mathrm{mm})\end{array}$ & $\begin{array}{l}\mathrm{Ig} \\
(\mathrm{mm})\end{array}$ \\
\hline 15-Dec & 32.3 & 0.4 & 12.92 & 0 & 0 & 12.93 & 21.55 \\
\hline 22-Dec & 31.8 & 0.4 & 12.72 & 0 & 0 & 12.72 & 21.2 \\
\hline 29-Dec & 31.4 & 0.4 & 12.56 & 0 & 0 & 12.56 & 20.93 \\
\hline 29-Dec & 32.3 & 0.4 & 12.92 & 0 & 0 & 12.93 & 21.55 \\
\hline 5-Jan & 32.7 & 0.5 & 16.37 & 0 & 0 & 16.37 & 27.28 \\
\hline 12-Jan & 29.2 & 0.6 & 17.82 & 0 & 0 & 17.82 & 29.7 \\
\hline 19-Jan & 33.6 & 0.7 & 24.51 & 0 & 0 & 24.51 & 40.86 \\
\hline 26-Jan & 37.8 & 0.8 & 31.78 & 0 & 0 & 31.78 & 52.96 \\
\hline 2-Feb & 34.5 & 1 & 32.77 & 0 & 0 & 32.77 & 54.61 \\
\hline 9-Feb & 35.9 & 1.1 & 38.39 & 0 & 0 & 38.39 & 63.99 \\
\hline 16-Feb & 41.4 & 1.1 & 45.49 & 0 & 0 & 45.49 & 75.81 \\
\hline 23-Feb & 37.1 & 0.9 & 31.49 & 0 & 0 & 31.49 & 52.49 \\
\hline 2-Mar & 31.8 & 0.9 & 27.02 & 0 & 0 & 27.02 & 45.04 \\
\hline 9-Mar & 32.2 & 0.9 & 27.34 & 0 & 0 & 27.34 & 45.57 \\
\hline 16-Mar & 32.3 & 0.9 & 27.43 & 0 & 0 & 27.43 & 45.72 \\
\hline 23-Mar & 34.4 & 0.9 & 29.20 & 0 & 0 & 29.2 & 48.66 \\
\hline 30-Mar & 41.7 & 0.9 & 35.40 & 0 & 0 & 35.4 & 59 \\
\hline Total & & & 436.14 & 0 & 0 & 436.14 & 726.9 \\
\hline
\end{tabular}

Note:CWR/ETc: Crop Water Requirement/Crop Evapotranspiration $\quad$ Peff:-Effective Rain fall ETo:-Reference Evapotranspiration Kc: - Crop Coefficient $\quad$ ETc=ETo $*$ Kc

\subsection{Yield and Yield Parameters}

\subsubsection{Onion bulb diameter}

Onion bulb diameter was measured using digital caliper in centimeter to grade the quality of onion produced. The analysis of variance for bulb diameter has shown a highly significant $(\mathrm{P}<0.01)$ difference among furrow irrigation methods and also a highly significant $(\mathrm{P}<0.01)$ difference among irrigation levels. The interaction of furrow irrigation methods and deficit irrigation level had no effect on onion bulb diameter (Table 6).

The CFI gave highest onion bulb diameter of $(6.69 \mathrm{~cm})$ and had no significant difference with AFI. The control irrigation $(100 \% \mathrm{ETc})$ gave significantly higher onion bulb diameter that has no significant difference with deficit irrigation of $(85 \% \mathrm{ETc})$ application. The smallest bulb size of $(6.45 \mathrm{~cm})$ was recorded from $70 \% \mathrm{ETc}$ irrigation application and significantly inferior to all other irrigation levels. In a similar study Demirtas and Serhat (2009) indicated that bulb diameter has increasing trend with increasing level of irrigation application.

\subsubsection{Onion bulb length}

The analysis of variance has shown that there was no significant difference among the difference furrow irrigation method and the interaction effect of furrow irrigation methods and deficit irrigation level on bulb length. 
Nevertheless, there was a highly significant $(\mathrm{P}<0.01)$ differences among the different irrigation levels on onion bulb length.

Significantly higher bulb length of $(5.97 \mathrm{~cm})$ was recorded from full irrigation $(100 \% \mathrm{ETc})$ application and had no significant difference with deficit irrigation application of $85 \%$ ETc. The shortest bulb height was recorded from deficit irrigation application of $70 \%$ ETc.The result indicated that the $70 \%$ ETc deficit irrigation level might have reduced transpiration and photosynthesis and assimilate available for growth of the crop, which thus caused to produce small bulbs. This result is in line with that of Olalla et al. (2004) who observed smaller sized bulbs in mild water-stressed onion plants. Similarly, Neeraja et al. (1999) reported that higher level of irrigation 1.2 Irrigation Water (IW): Cumulative Pan Evaporation (CPE) resulted in maximum bulb length.

Table 6. Effect of furrow irrigation methods and deficit irrigation levels on bulb diameter and bulb height of onion

\begin{tabular}{lcc}
\hline Furrow Irrigation method & $\mathrm{BD}(\mathrm{cm})$ & $\mathrm{BH}(\mathrm{cm})$ \\
\hline CFI & $6.69 \mathrm{a}$ & 5.74 \\
AFI & $6.37 \mathrm{ab}$ & 5.68 \\
FFI & $6.04 \mathrm{~b}$ & 5.52 \\
\hline LSD(P=0.05) & 0.52 & $\mathrm{~ns}$ \\
\hline Irrigation level & & \\
$100 \%$ & $6.94 \mathrm{a}$ & $5.97 \mathrm{a}$ \\
$85 \%$ & $6.56 \mathrm{ab}$ & $5.66 \mathrm{ab}$ \\
$70 \%$ & $6.45 \mathrm{~b}$ & $5.64 \mathrm{bc}$ \\
\hline LSD(P=0.05) & 0.47 & 0.32 \\
CV1 Main plot $(\%)$ & 7.9 & 5.74 \\
CV2 Sub plot $(\%)$ & 7.39 & 4.91 \\
\hline
\end{tabular}

\subsubsection{Marketable Bulb Yield}

Marketable bulb yield are not under sized $(>5 \mathrm{~cm}$ in diameter), free from physiological disordered and pest damaged bulbs. Onion bulbs with greater than $5 \mathrm{~cm}$ diameter were categorized under marketable and less than $5 \mathrm{~cm}$ diameter unmarketable bulb yield (Moray et al., 2012).

Analysis of variance has shown that marketable bulb yield of onion was significantly affected $(P<0.01)$ by the furrow irrigation methods and irrigation level. Similarly, interaction effect of furrow irrigation methods and irrigation level has significantly $(\mathrm{P}<0.05)$ affected marketable bulb yield of onion.

The CFI practice with irrigation scheduled at the control $(100 \% \mathrm{ETc})$ application gave significantly highest marketable bulb yield of $\left(42219 \mathrm{~kg} \mathrm{ha}^{-1}\right)$. This result seems closely related to that of Yemane et al. (2018), who reported that CFI methods with $100 \%$ ETc deficit irrigation application gave the highest marketable bulb yield. Among the deficit irrigation levels, $85 \%$ ETc and $70 \%$ ETc under the CFI and the AFI practices have shown no significant difference on marketable bulb yield. Generally, among the furrow irrigation methods, CFI and AFI produced the best marketable bulb yield and while significantly lowest mean marketable bulb yield were obtained from FFI and 70\%ETc application.

Yemane et al, (2018) reported that small amount of applied water reduced yield in every other furrow irrigation (AFI and FFI) as compared to CFI due to water stress, when the same irrigation frequency was applied which supported the result of this study.

The present result agreed with the general principle that the response of crop to full irrigation is generally higher under irrigated conditions than none irrigated one (Michael, 1978). Similar to the present observation Patel and Rajput (2013) also reported that water application with no deficit (100\% full Crop water requirements) at any stage of plant growth gave highest marketable yield. Results of De santa et al. (1994), Neeraja et al. (1999) and Bosch sera and Currah (2002) also showed that marketable bulb yield of onion increased with increasing irrigation water amount is a linear fashion.

Similar results were also reported by Kloss et al. (2012) who showed that dealing with improvement of water productivity is closely related to the irrigation practice of regulated deficit irrigation and has a direct effect on yield i.e., if the amount of water applied decreases similarly the crop yield will also drop. 
Table 7.Effects of furrow irrigation methods and deficit irrigation levels on marketable bulb yield of onion.

\begin{tabular}{lllll}
\hline \multirow{2}{*}{ Treatments } & \multicolumn{4}{l}{ Marketable bulb yield of onion $\left(\mathrm{kg} \mathrm{ha}^{-1}\right)$} \\
\cline { 2 - 5 } & \multicolumn{4}{l}{ Deficit Irrigation level $(\%)$} \\
\hline Furrow Irrigation method & 100 & 85 & 70 & Mean \\
\hline CFI & $42219^{\mathbf{a}}$ & $34489^{\mathbf{c}}$ & $32930^{\mathbf{c d}}$ & $34494.5^{\mathbf{a}}$ \\
AFI & $38823^{\mathbf{b}}$ & $34348^{\mathbf{c}}$ & $32117^{\text {cd }}$ & $33406.3^{\mathbf{a}}$ \\
FFI & $31449 \mathrm{~d}$ & $28237^{\mathbf{e}}$ & $27337^{\mathbf{e}}$ & $27698.8^{\mathbf{b}}$ \\
\hline Mean & $37497^{\mathbf{a}}$ & $32358^{\mathbf{b}}$ & $30794.8^{\mathbf{c}}$ & \\
LSD(P=0.05) & 2371.8 & & & \\
CV1 Main plot (\%) & 10.21 & & & \\
CV2 Sub plot (\%) & 4.34 & & & \\
\hline
\end{tabular}

Means in a Colum with the same superscripts are not significantly different at $P \geq 0.05$

\subsubsection{Unmarketable bulb yield}

The analysis of variance has shown that unmarketable bulb yield was not significantly affected by interaction effect of furrow irrigation methods and irrigation levels. Furrow irrigation methods and irrigation levels had a highly significant $(P<0.001)$ influence on unmarketable bulb yield (Table 8$)$.

The CFI gave the lowest unmarketable bulb yield and was not significantly different from AFI. The control irrigation $(100 \% \mathrm{ETc})$ also had the lowest unmarketable bulb yield and among the deficit irrigation levels, the $85 \%$ ETc application gave significantly lowest unmarketable bulb yield. Moreover, the highest unmarketable bulb yields were recorded from the FFI practice and deficit irrigation application of $70 \% \mathrm{ETc}$.

Stressed onion plants may bulb too early, produce small-sized bulbs and high amount of unmarketable yield (Kebede, 2003).This could be due to low rate of transpiration caused by stomata closer under moisture stress condition which brought about reduced photosynthesis and poor bulb growth and developments. Corresponding to this, Martin et al. (2004), Olalla et al. (2004) and Zayton (2007) reported that plots which received the lowest amount of water during the development and maturing stages produced higher percentage of small size bulbs. From present result, increasing water deficit had a positive relationship with the production of high yield of under size bulbs.

\subsubsection{Total bulb yield}

The total bulb yield which is the sum of unmarketable and marketable bulb yield. The furrow irrigation method and irrigation level have shown a highly significance $(P<0.01)$ difference on total bulb yield (Table 8). The analysis of variance has shown that unmarketable bulb yield was not significantly affected by interaction effect of furrow irrigation method and irrigation level.

The AFI gave the maximum total bulb yield of $\left(35920 \mathrm{~kg} \mathrm{ha}^{-1}\right)$ and had no significant difference with CFI practice. In fact significantly highest bulb yield was obtained from the control irrigation (100\%ETc). However, from deficit irrigation levels, the $85 \%$ ETc application gave the highest total bulb yield and significantly different to all other deficit irrigation levels. Significantly lowest total bulb yield was obtained from the FFI practice and from deficit irrigation application of $70 \%$ ETc application.

The increment in onion total bulb yield might be attributed to large size of onion bulb due to application of maximum amount irrigation water. This is because that it encourages cell elongation, above ground vegetative growth and imparts dark green color of leaves, which is important for more assimilate production and partition that favors onion bulb growth. Crops irrigated under AFI physiologically respond the water stress by producing signals to control the leaf water potential, so that transpiration loss can be significantly reduced (Kang et al., 2000; Zhang et al., 2000).

The increased total bulb yield by applying full irrigation could have better performance on vegetative growth like plant height, number of leaves and leaf length which increase photosynthetic capacity of the plant, which in turn can improve bulb weight and contribute to increment in total bulb yield. As the irrigation level increased from $70 \%$ ETc to $100 \%$ ETc, the total bulb yield increased. 
Table 8. Effect of furrow irrigation methods and irrigation levels on Unmarketable Bulb Yield (UMBY) and Total Bulb Yield (TBY).

\begin{tabular}{lll}
\hline Furrow Irrigation method & $\mathrm{UMBY}\left(\mathrm{kg} \mathrm{ha}^{-1}\right)$ & $\mathrm{TBY}\left(\mathrm{kg} \mathrm{ha}^{-1}\right)$ \\
\hline CFI & $1335.4^{\mathrm{b}}$ & $35830^{\mathrm{a}}$ \\
AFI & $1679.9^{\mathrm{b}}$ & $35920^{\mathrm{a}}$ \\
FFI & $2554.3^{\mathrm{a}}$ & $30253^{\mathrm{b}}$ \\
\hline LSD $(\mathrm{P}=0.05)$ & 481.6 & 4842.4 \\
\hline Irrigation level (\%) & \\
\hline 100 & & $38947^{\mathrm{a}}$ \\
85 & $1449.87^{\mathrm{d}}$ & $35175^{\mathrm{b}}$ \\
70 & $1705.57^{\mathrm{c}}$ & $32747^{\mathrm{c}}$ \\
\hline LSD $(\mathrm{P}=0.05)$ & $1951.93^{\mathrm{b}}$ & 2130.9 \\
CV1 Main plot $(\%)$ & 182.12 & 12.56 \\
CV2 Sub plot $(\%)$ & 22.89 & 6.33 \\
\hline
\end{tabular}

Means with the same superscript in a column are not significantly different at $P \geq 0.0$

\subsection{Irrigation Level and Furrow Irrigation Methods on IWUE and CWUE}

\subsubsection{Irrigation water use efficiency}

Irrigation water use efficiency (IWUE) is considered as relative bulb yield per unit of irrigation water used. The analysis of variance has shown that the interaction of furrow irrigation methods and deficit irrigation levels significantly $(P<0.05)$ affected IWUE and whilst a highly significant $(\mathrm{P}<0.01)$ effect was observed from furrow irrigation methods and irrigation levels on IWUE (Table 9). The highest IWUE of $\left(12.62 \mathrm{~kg} \mathrm{~m}^{-3}\right)$ was recorded from AFI practice with the $70 \%$ ETc deficit irrigation application and significantly different from all other treatments. The AFI practice gave best IWUE compared to other furrow irrigation methods. The lowest irrigation water use efficiency of $\left(5.58 \mathrm{kgm}^{-3}\right)$ was obtained from CFI practice with $85 \%$ ETc deficit irrigation application and had no significant difference with control irrigation $(100 \% \mathrm{ETc})$ application under CFI practices.

Generally, IWUE was influenced by crop yield potential, irrigation method, estimation and measurement of ET, and crop environment. The results related to the efficiencies showed that when irrigation water is limited, $70 \%$ deficit irrigation can be applied by increasing the water use efficiency. Mansouri-Far et al. (2010) reported that irrigation water can be conserved and yields maintained (as sensitive crop to drought stress) under water limited conditions.

Table 9. Effect of furrow irrigation methods and deficit irrigation levels on irrigation water use efficiency of onion

\begin{tabular}{|c|c|c|c|c|}
\hline \multirow{2}{*}{ Treatments } & \multicolumn{4}{|c|}{ irrigation water use efficiency $\left(\mathrm{kg} \mathrm{m}^{-3}\right)$} \\
\hline & \multicolumn{4}{|c|}{ Deficit irrigation level (\%) } \\
\hline Furrow Irrigation method & 100 & 85 & 70 & Mean \\
\hline CFI & $5.81^{\mathrm{g}}$ & $5.58^{\mathrm{g}}$ & $6.47^{\mathrm{fg}}$ & $6.24^{\mathrm{c}}$ \\
\hline AFI & $10.68^{\mathrm{d}}$ & $11.12^{\mathrm{cd}}$ & $12.62^{\mathrm{b}}$ & $12.15^{\mathrm{a}}$ \\
\hline FFI & $8.65^{\mathrm{e}}$ & $9.14^{\mathrm{e}}$ & $10.75^{\mathrm{d}}$ & $10.11^{\mathrm{b}}$ \\
\hline Mean & $8.40^{\mathrm{c}}$ & $8.61^{\mathrm{c}}$ & $9.95^{\mathbf{b}}$ & $11.10^{\mathrm{a}}$ \\
\hline $\operatorname{LSD}(\mathrm{P}=0.05)$ & 0.87 & & & \\
\hline CV1 Main plot (\%) & 9.80 & & & \\
\hline CV2 Sub plot $(\%)$ & 5.31 & & & \\
\hline
\end{tabular}

\subsubsection{Crop water use efficiency}

The crop water use efficiency (CWUE) in the study measures the effectiveness of the irrigation levels and furrow irrigation methods in converting the total water applied to onion bulb yield. The analysis of variance has shown that the interaction of furrow irrigation methods and deficit irrigation levels significantly $(P<0.05)$ affected CWUE and whilst a highly significant $(\mathrm{P}<0.01)$ effect was observed under furrow irrigation methods and irrigation levels on CWUE (Table 11).

As depicted in Table 10, the highest CWUE of $\left(17.91 \mathrm{~kg} \mathrm{~m}^{-3}\right)^{-}$was achieved with $70 \%$ ETc deficit irrigation application with AFI practice and this was significantly different from the CWUE in all treatment combinations. All deficit levels with AFI and CFI systems attained, respectively, the highest and lowest CWUE. The results of these research findings are in agreement with Hamed et al. (2011), who reported that the reason of having more CWUE and lower reduction in the yield for AFI could be related to better distribution of the roots in both sides of the ridge. It could increase water and fertilizer uptakes by plants. The results showed that alternative drying of the root zone had better performance than the fixed drying of the root zone. The results showed that AFI increased CWUE for onion relative to CFI.

In line with this result, Samson and Ketema (2007) reported that deficit irrigations increased the water use 
efficiency of onion. Similarly, Shock et al., (1998), Kebede (2003), Kirnak et al. (2005) and Sarkar et al. (2008) reported that crop water use efficiency was higher at lower levels of available soil moisture.

Table 10. Effect of furrow irrigation methods and deficit irrigation levels on crop water use efficiency of onion

\begin{tabular}{lllll}
\hline \multirow{2}{*}{ Treatments } & \multicolumn{4}{l}{ Crop water use efficiency $\left(\mathrm{kgm}^{-3}\right)$} \\
\cline { 2 - 5 } & \multicolumn{4}{l}{ Deficit irrigation level $(\%)$} \\
\hline Furrow Irrigation method & 100 & 85 & 70 & Mean \\
\hline CFI & $9.68^{\mathrm{g}}$ & $9.30^{\mathrm{g}}$ & $10.78^{\mathrm{fg}}$ & $10.39^{\mathbf{c}}$ \\
AFI & $17.80^{\mathrm{d}}$ & $18.53^{\mathrm{cd}}$ & $21.04^{\mathrm{b}}$ & $20.25^{\mathrm{a}}$ \\
FFI & $14.42^{\mathrm{e}}$ & $15.24^{\mathrm{e}}$ & $17.91^{\mathrm{d}}$ & $16.85^{\mathrm{b}}$ \\
\hline Mean & $14.00^{\mathrm{c}}$ & $14.14^{\mathrm{c}}$ & $16.60^{\mathrm{b}}$ & $18.40^{\mathrm{a}}$ \\
LSD (P=0.05) & 1.44 & & & \\
CV1 Main plot (\%) & 9.80 & & & \\
CV2 Sub plot (\%) & 5.31 & & & \\
\hline
\end{tabular}

\subsubsection{Onion bulb yield response to deficit irrigation}

The response of onion yield to water supply as quantified through yield response factor (Ky) is given in (Table 12). The Ky ranged from 0.15 to 1.16 , where both the lowest and the highest being from $85 \%$ ETc application under AFI and CFI, respectively. Generally, it can be observed that Ky decreasing with decreasing onion bulb yield and increasing in irrigation water deficit. The crop yield response factor (Ky) captures the essence of the complex linkages between production and water use by a crop. Crop yield response factor indicates a linear relationship between the decrease in relative water consumption and the decrease in relative yield. The ky values greater than unity indicates the relative yield decrease is higher than the water deficit as stated by Smith and Kivumb (2002). According to Kirda et al. (1999), the ky value for field crops goes from 0.2 to 1.15 which agrees with the reported result.

Doorenbos and Kassam (1979) reported the effect of water deficit on crop yield, deficit occurring for the total growing period, the decrease in yield is proportionally less with the increase in water deficit. Under conditions of limited water distributed equally over the total growing season, involving crops with different Ky values, the crop with the higher Ky value will suffer a greater yield loss than the crop with a lower Ky value.

Table 11. The yield response factor values for irrigation treatments

\begin{tabular}{|c|c|c|c|c|c|c|c|c|}
\hline $\begin{array}{l}\text { Irrigation } \\
\text { method }\end{array}$ & $\begin{array}{l}\text { Deficit level } \\
(\%)\end{array}$ & $\begin{array}{l}\text { Yield } \\
\left(\mathrm{kg} \mathrm{ha}^{-1}\right)\end{array}$ & $\begin{array}{l}\mathrm{ET}_{\mathrm{a}} \\
(\mathrm{mm})\end{array}$ & $\frac{\mathrm{ET}_{\mathrm{a}}}{\mathrm{ET}_{\mathrm{m}}}$ & $\frac{Y_{a}}{Y_{m}}$ & $1-\frac{\mathrm{ET}_{\mathrm{a}}}{\mathrm{ET}_{\mathrm{m}}}$ & $1-\frac{Y_{a}}{Y_{m}}$ & $\mathrm{~K}_{\mathrm{y}}$ \\
\hline \multirow[t]{3}{*}{$\overline{\mathrm{CFI}}$} & 100 & 43251 & 436.14 & 1.00 & 1.00 & 0.00 & 0.00 & - \\
\hline & 85 & 35756 & 370.72 & 0.85 & 0.83 & 0.15 & 0.17 & 1.16 \\
\hline & 70 & 34296 & 305.30 & 0.7 & 0.79 & 0.30 & 0.21 & 0.69 \\
\hline \multirow[t]{3}{*}{$\overline{\mathrm{AFI}}$} & 100 & 40102 & 218.07 & 1.00 & 1.00 & 0.00 & 0.00 & - \\
\hline & 85 & 36179 & 185.36 & 0.85 & 0.90 & 0.15 & 0.10 & 0.65 \\
\hline & 70 & 33875 & 152.65 & 0.7 & 0.84 & 0.30 & 0.16 & 0.52 \\
\hline \multirow[t]{3}{*}{ FFI } & 100 & 33488 & 218.07 & 1.00 & 1.00 & 0.00 & 0.00 & - \\
\hline & 85 & 30589 & 185.36 & 0.85 & 0.91 & 0.15 & 0.09 & 0.58 \\
\hline & 70 & 28069 & 152.65 & 0.7 & 0.84 & 0.30 & 0.16 & 0.54 \\
\hline
\end{tabular}

Note Eta: Actual Evapotranspiration ETm: Maximum Evapotranspiration Ya: Actual Yield Ym: Maximum Yield Ky:Yield Response Factor

\section{CONCLUSION}

Based on the result arisen from the research when less irrigation water was applied, the conventional furrow irrigation techniques had the smallest bulb yield reduction. The maximum total bulb yield of $\left(35920 \mathrm{~kg} \mathrm{ha}^{-1}\right)$ was recorded at Alternative Furrow Irrigation Method. Although 70\%ETc application under alternate furrow irrigation gave the highest Crop Water Use Efficiency and Irrigation Water Use Efficiency, yield penalty was significant compared to all other deficit irrigation. However, deficit irrigation of $70 \% \mathrm{ETc}$ under alternate furrow irrigation gave above the mean value of crop water use efficiency and irrigation use efficiency. The most important result arisen from this investigation was water under deficit irrigation with the combination of Alternative Furrow Irrigation (AFI) are a promising practice that can be adopted as alternative for irrigating intensive field crop like Onion; but more studies have to be conducted under similar field conditions.

\section{ACKNOWLEDGMENTS}

I would like to thank Ethiopian Institute of Agricultural Research, for providing funds for the experiment and 
technical support for masters of Thesis. I also very grateful to Debre Zeit Agricultural research center for all staff of Natural Resources Management Research core process and my friends for giving us support in field management, suggestion and technical guidance during the course of the study experiment. Additionally Hawassa University Institute of Technology Water Resource and Irrigation Engineering Department Lecturers and Staffs giving support in my master's course I would like to thank.

\section{References}

Aranus, JL, Villcgas D, Aparicio N, Garcia del Moral LF, El Hani S, Rharrabti Y, Ferrio JP, and Royo C (2003). Environmental factors determining carbon isotope discrimination and yield in durum wheat under Mediterranean conditions. Crop Science 43: 170-180.

Bauder, TA.,Waskom, R.M.,Suthernland,P.L and Davis J.K (2014). Irrigation water quality Criteria, Colorado State University: Fact Sheet No. 0.506.www.ext.colostate.edu.

Bosch, A.D. Serra, and Currah L (2002). Agronomy of Onions. pp, 187-224. In: Rabinowitch, H.D., and Currah, L (eds). Alliums Crop Sciences: Recent Advance CABI publishing.

Brady, N.C. and Weil R.R (2002). The nature and Properties of Soils. 13th ed. Person Education Ltd., USA.

Bryan, G.,Donald, A., and Robert, G (2007).managing irrigation water quality for crop production, Washington state university.

CSA (Central Statistical Agency) (2015/16). Agriculture sample survey. Central Statistical Agency, Addis Ababa, Ethiopia, Bulletin, 1: 584.

De santa, O.F.M., Dejuan Valero J.A. and Fabrio corles C (1994). Growth and production of onion crop (Allium cepa L.) under different irrigation scheduling. European Journal of Agronomy, 3: 85-92.

Demirtaş C.and Serhat A. 2009. Deficit irrigation effects on onion (Allium cepa L.) yield in unheated greenhouse condition. Journal of Food and Agricultural Environment 7:239 -24

Doorenbos, J.and Kassam A.H (1979). Yield Response to Water. FAO Irrigation and Drainage Paper Number, 33 , Rome.

Falkenmark, M. and Rockstrom J (2000). Semiarid crop production from hydrological perspective: Gap between potential and actual yield, Crit. Rev. Plant Sci. 19(4): 319-346.

FAO (Food and Agricultural organization) (2002). Deficit irrigation practices. Water reports, 22. FAO, Rome, Italy.

FAOSTAT (Food and Agriculture Organization Statistics ) (2008). List of countries by onion production. Food and Agricultural Organization of United Nations, Rome, Italy.

FAO (Food and Agricultural Organization) (2011).World Agricultural Land http://www.wendellkrossa.com/wpcontent/uploads/2011/07/World-Agricultural-Land.doc

FAOSTAT (Food and Agriculture Organization Statistics) (2011). Statistical Year Book; Food and Agriculture Organization of the united nations, Rome, Italy. http://faostat3.fao.org/home/E.

FAO: AQUASTAT database (Food and Agriculture Organization of the United Nation).2013.Rome, Italy, http://www.fao.org/nr/water/ aquastat/main/index.stm (last access: 12 March (2015).

Fekadu, Marame and Dandena Gelmesa. (2006). Review of the status of vegetable crops production and marketing in Ethiopia. Uganda Journal of Agricultural Sciences 12(2): 26-30.

Hamed, E., Abdolmajid, L., Massoud, P.,Fariborz,A. and Maryam,(N.2011).Yield production and water use efficiency under conventional and alternate furrow fertigations. ICID $21^{\text {st }}$ International congress on irrigation and drainage. Tehran, Iran.15-23

Kang, S., Liang, Z., Hu, W. and Zhang, J (1999). Water use efficiency of controlled root division alternate irrigation on maize plants. Agricultural Water Management. 38: 69-76.

Kang, S., Z. Liang, Y.Pan and J.Zhang (2000). Alternate furrow irrigation for maize production in an arid area. Journal Agricultural Water Management.45:267-274.

Kebede Woldetsadik (2003). Shallot (Allium cepa var, ascolonicum) Responses to Plant Nutrients and Soil Moisture in a Sub- humid Tropical Climate. Swedish University of Agricultural Sciences, PhD Thesis, 311P.

Kebede Woldetsadik (2003). Shallot (Allium cepa var. ascalonicum) responses to plant nutrient and soil moisture in a sub- humid tropical climate. Journal of Horticultural Science and Biotechnology, 78(4):549-555.

Kirda, C. and Kanber R (1999). Water, no longer a plentiful resource, should be used sparingly in irrigated agriculture. In: Kirda C. P. ,Moutonnet ,Hera C. and Nielsen D.R., eds. Crop yield response to deficit irrigation. Kluwer Academic Publishers. Dordrecht. The Netherlands.

Kirnak, H., Higgs D, Kaya C., and Tas I (2005). Effects of irrigation and nitrogen rates on growth, yield, and quality of musk melon in semiarid regions. Journal of Plant nutrition, 28: 621-638.

Kloss, S., Pushpalatha R., Kamoyo KJ.and Schütze (2012). Evaluation of crop models for simulating and optimizing deficit irrigation systems in arid and semi-arid countries under climate variability. Water Resource Management 26(4):997-1014.

Lemma Dessalegn and Shemelis Aklilu (2003).Research results and experiences in onion dry bulb and seed 
production in Ethiopia. Vegetable crops improvement research, EARO, Melkassa Agricultural Research Centre. p39.

Mansouri-Far, C., Sanavy, S.A.M.M., and Saberali S.F (2010). Maize yield response to deficit irrigation during low-sensitive growth stages and nitrogen rate.

Martin de Santa Olalla, De Juan Valero F. J.A and Cortes F (2004).Growth and production of onion Crop (Allium cepa L.)Under different irrigation scheduling, European Journal of Agronomy, 3(1), 85-92.

Mekonen Ayana (2011). Deficit irrigation practices as alternative means of improving water use efficiencies in irrigated agriculture: Case study of maize crop at Arba Minch, Ethiopia. African Journal of Agricultural Resource 6(2): 226-235.

Michael, A. M (1978). Irrigation Theory and Practice, Vikas Publishing House PVT Ltd. Jupiter Offset Press, Shahdara - Delhi-India

Molden, D (2003). Pathways to improving productivity of water. In: Jinendradasa, S.S. (ed.) Issues of water management in agriculture: compilation of essays. IWMI, Colombo, Sri Lanka.

Moray, M.G., Marey R.A., Karam S.S ,Abo-Dahab, and A.M.A (2012).Productivity and storability of onion as influenced by the different levels of NPK fertilization. Agricultural Research, 38 (1): 171-187.

Murphy H.F (1968).A report on fertility states and other data on some soils of Ethiopia collage of Agriculture HSIU. Experimental Station Bulletin No.44 Collage of Agriculture: 551p.

Neeraja, G., Reddy K.M., Reddy I.P. and Reddy Y.N (1999). Effect of irrigation and nitrogen on growth, yield and yield attributes of rabi onion (Allium cepa L.) in Andhra Pradesh. Vegetable Science, 26(1): 64-68.

Nelson, D. W. and L. Sommers E (1996). Total carbon, organic carbon, and organic matter. In: Sparks D. L., Page A. L., Helmke P. A., Loeppert R. H., Soltanpour P. N., Tabatabai M. A., Johnston C. T. \& Sommers M. E. (eds), Methods of Soil Analysis. Part 3: Chemical Methods. American Society of Agronomy and Soil Science Society of America. Madison, Wisconsin. pp961-1010.

Olalla, F.S., Padilla A. D. and Lopez R (2004). Production and quality of the onion crop (Allium cepa L.) cultivated under controlled deficit irrigation conditions in a semi-arid climate. Agricultural Water Management, 68: 77-89.

Olani Nikus and Fikre Mulugeta (2010). Onion seed production techniques. A Manual for Extension Agents and Seed Producers. Asella, Ethiopia.

Patel and Rajput(2013). Effect of deficit irrigation on crop growth, yield and quality of onion in sub-surface drip irrigation. International Journal of Plant Protection, 7(3): 1735

Rowell D.L (1994).Soil science: Method and applications.Longman Scientific and Technical, Longman Group UK Limited Addison, Wesley, England.350p.

Samson Bekele and Ketema Tilahun (2007).Regulated deficit irrigation scheduling of onion in a semiarid region of Ethiopia. Agricultural water management. 89:148-152.

Sarkar, S., Goswami S.B., Mallick S. and Nanda M.K (2008). Different indices to characterize water use pattern of micro-sprinkler irrigated onion (Allium cepa L.). Journal of Agricultural Water Management, 95: 625632.

Seleshi Bekele, Wakena T., Philippe L., Nigatu Alemayehu and Kiflu Getahun(2006). Assessment of water resources and recommendation to improve water Resources management Final Draft Report. International Water Management Institute (IWMI), Oromia, Ethiopia.

Shock, C.C., Feibert E.B.G. and saunders L.D (1998). Onion yield and quality affected by soil water potentials as irrigation threshold. Horticultural Science 33, 1188-1191.

Smith, M. and Kivumbi D (2002). Use of the FAO CROPWAT model in deficit irrigation studies Food and Agriculture Organization, Rome, Italy.

Smith, R., A. Biscaro, M. Cahn, O. Daugovish, E. Natwick, J. Nunez, E. Takele, and T. Turini (2011). Freshmarket bulb onion production in california. Publication 7242. University of California, Agricultural and Natural Resource Center. California.

Tekalign Tadese (1991).Soil, plant, water, fertilizer, animal manure and compost analysis. Working document No.13. International Livestock Research Center for Africa, Addis Ababa, Ethiopia.

Walkley, A. and Black I.A (1934). An Examination of the Degtjareff Method for Determination of Soil Organic Matter and Proposed Modification of the Chronic Acidification Method. Soil Science 37. Pp29-38.

World Bank (2004).Opportunities and challenges for development of high value agricultural exports in Ethiopia. The World Bank Report No 14,World Bank.Washington, DC

WRB (World Reference Base) (2014). International soil classification system for naming soils and creating legends for soil maps, world soil resource report 106, Rome.p180

Yemane Mebrahtu, Abraham Woldemichael and Solomon Habtu (2018).Response of onion (Allium cepa 1.) to deficit irrigation under different furrow irrigation water management techniques in Raya Valley, Northern Ethiopia. African Journal of Plant Science .12(5), pp. 105-113.

Zayton, A. M (2007). Effect of water stress on onion yield and quality in sandy soil. Journal of Agricultural 
Engineering, 24(1): 141-160

Zhang, J., Kang S., Liang. Z., Pan, Y.Z., Shi, P., Pan, Y.H., Liang, Z.S. and Hu X.T(2000). Soil water distribution, uniformity and water use efficiency under alternate furrow irrigation in arid areas. Irrigation Science 19: 181190. 